\title{
Soil Fertility, Sugarcane Yield Affected by Limestone, Silicate, and Gypsum Application
}

\section{Carlos Alexandre Costa Crusciol, Otavio Bagiotto Rossato, Rodrigo Foltran, Jorge Martinelli Martello \& Carlos Antonio Costa do Nascimento}

To cite this article: Carlos Alexandre Costa Crusciol, Otavio Bagiotto Rossato, Rodrigo Foltran, Jorge Martinelli Martello \& Carlos Antonio Costa do Nascimento (2017) Soil Fertility, Sugarcane Yield Affected by Limestone, Silicate, and Gypsum Application, Communications in Soil Science and Plant Analysis, 48:19, 2314-2323, DOI: 10.1080/00103624.2017.1411507

To link to this article: https://doi.org/10.1080/00103624.2017.1411507

册 Published online: 06 Dec 2017.

Submit your article to this journal

Џ Article views: 67

View Crossmark data ¿ 


\title{
Soil Fertility, Sugarcane Yield Affected by Limestone, Silicate, and Gypsum Application
}

\author{
Carlos Alexandre Costa Crusciol, Otavio Bagiotto Rossato, Rodrigo Foltran, \\ Jorge Martinelli Martello, and Carlos Antonio Costa do Nascimento (D) \\ Department of Crop Science, College of Agricultural Sciences, Sao Paulo State University, Botucatu, State of São \\ Paulo, Brazil
}

\begin{abstract}
The aim of this study was to verify if the application of silicate or lime, in association with gypsum, on sugarcane residue can lead to amendment of subsurface soil acidity, increasing sugarcane yield and profitability. The treatments were: 1 - control (without application of amendments), 2 - gypsum, 3 - dolomitic limestone, 4 - silicate, 5 -dolomitic limestone + gypsum, and 6 - silicate + gypsum. The surface application of gypsum led to reduction in $\mathrm{Al}$ (aluminum) contents and $\mathrm{Al}$ saturation, and increase in $\mathrm{Mg}^{+2}, \mathrm{Ca}^{+2}, \mathrm{~K}^{+}$, $\mathrm{S}_{-} \mathrm{SO}_{4}{ }^{-}$, and base saturation in deeper soil layers, as well as increased yield of stalks, sugar, trash, bagasse, and energy, and greater profit. The application of limestone and silicate, alone or in association with gypsum, amend soil acidity throughout the soil profile. It likewise leads to an increase in stalk, sugar, trash, bagasse, and energy yield, however, application of silicate in association with gypsum leads to the greatest profitability.
\end{abstract}

\section{ARTICLE HISTORY}

Received 20 December 2016 Accepted 22 September 2017

\section{KEYWORDS}

Sacharum spp.; soil acidity correctives; soil properties; stalks; surface

\section{Introduction}

Soil acidity is one of the most yield-limiting factors for crop production. Land area affected by acidity is $30 \%$ of the total ice-free land area of the world (Sumner and Noble 2003). Considering that about $70 \%$ of all agricultural lands in Brazil consist of acid soils, crop yield may be decreased by aluminum ( $\mathrm{Al}$ ) and $\mathrm{Mn}$ (manganese) toxicity, as well as low availability of exchangeable bases (Soratto and Crusciol 2008). Therefore, amendment of soil acidity is essential for appropriate crop development.

The most recommended practice for amendment of soil acidity is liming. The materials used in the amendment of soil acidity are basically oxides, hydroxides, silicates, and carbonates. In addition to the use of substances for the amendment of acidity, gypsum $\left(\mathrm{CaSO}_{4} \cdot 2 \mathrm{H}_{2} \mathrm{O}\right)$ has been used as a soil conditioner. It exhibits high mobility in the soil profile and is able to make $\mathrm{Ca}^{2+}$ and $\mathrm{SO}_{4}{ }^{2-}$ ions available in the soil solution. It is subject to leaching, enriching the deeper subsurface soil layers with nutrients, reducing $\mathrm{Al}^{3+}$ saturation at these depths and reducing $\mathrm{Al}^{3+}$ activity in the soil solution (Caires, Joris, and Churka 2011).

Lime application recommendations for amendment of soil acidity in sugarcane were developed for a burnt cane harvesting system. Sugarcane harvest without burning is already a reality and has been growing significantly; however, lime application for amendment of soil acidity in this system in which the crop residue remains on the ground has been carried out without a scientific basis.

Studies on amendment of soil acidity in grain crops under no-tillage have shown that the effect of lime applied on the surface for subsoil amendment varies with the rate and particle size of the product, form of application, soil type, climatic conditions (especially water regime), cropping 
system, and time since application (Caires et al. 2006; Soratto and Crusciol 2008). The variability of these factors places the efficiency of soil amendment in question, particularly, the amendment of subsoil acidity.

More recently, farmers and sugar mills have used silicates to amend soil acidity. Calcium and magnesium silicate is an original source from high temperature processing and reaction of limestone with silica $\left(\mathrm{SiO}_{2}\right)$, present in iron ore, with acidity amendment properties similar to those of limestone (Castro and Crusciol 2013). Studies on silicates applied to the soil have shown increased $\mathrm{pH}$ and reduced $\mathrm{H}+\mathrm{Al}$, and increased availability of $\mathrm{P}$ (phosphorus), $\mathrm{Ca}^{2+}, \mathrm{Mg}^{2+}$, and $\mathrm{Si}$ (silicate) in soil, which has led to yield increases for some crops (Pulz et al. 2008).

In replanting sugarcane, it is known that soils after liming have decreased base saturation and decreases in $\mathrm{Ca}^{2+}, \mathrm{Mg}^{2+}$, and $\mathrm{K}^{+}$throughout the cut areas (Morelli et al. 1992). It is also known that there is a progressive decline in production associated with the decline in soil fertility, which after successive cuttings will culminate in the need for replanting the sugarcane, which is one of the most expensive phases of the production system. Therefore, it is necessary to verify if the application of calcium-magnesium silicate or lime, in association with gypsum, on sugarcane residue can lead to amendment of acidity in subsurface soil, increasing sugarcane yield.

Thus, the aim of this study was to evaluate amendment of soil acidity, stalk, sugar, and trash yield, and crop income when lime, silicate, and gypsum are applied on the surface of ratoon cane.

\section{Materials and methods}

The experiment was carried out after the 2rd ratoon harvest of the variety SP 81-3250 in a commercial green sugarcane plantation of the São Luiz Sugar Mill (47²5'33” W; 21 $559^{\prime} 46^{\prime \prime}$; altitude $627 \mathrm{~m}$ above sea level), in Pirassununga, state of São Paulo, in southeast Brazil, for one year. The climate is Aw (Tropical Savanna, by the Köppen classification) and the area is flat. Daily rainfall was measured during the experiment, registering $102 \mathrm{~mm}$ in October, $120 \mathrm{~mm}$ in November, $175 \mathrm{~mm}$ in December, $275 \mathrm{~mm}$ in January, $172 \mathrm{~mm}$ in February, $164 \mathrm{~mm}$ in March, $62 \mathrm{~mm}$ in April, $58 \mathrm{~mm}$ in May, $18 \mathrm{~mm}$ in June, $15 \mathrm{~mm}$ in July, $15 \mathrm{~mm}$ in August, $28 \mathrm{~mm}$ in September, and $84 \mathrm{~mm}$ in October, for a total of $1,288 \mathrm{~mm}$.

The soil is classified as kaolinitic, thermic Typic Haplorthox, with a sandy loam texture. Immediately after the harvest of the second ratoon and before initiating the experiment, the soil chemical and textural characteristics were determined. Thus, ten subsamples were taken from the experimental area between the ratoon rows and combined into one composite sample with the following results for the topsoil $(0.00-0.20 \mathrm{~m})$ and subsoil $(0.20-0.40 \mathrm{~m})$, respectively: $\mathrm{pH}$ of 4.8 and 4.7, soil organic matter $(\mathrm{OM})$ of 23.6 and $16.8 \mathrm{~g} \mathrm{dm}^{-3}, \mathrm{P}$ (resin) of 7.0 and $4.0 \mathrm{mg} \mathrm{dm}^{-3}$, Si of 5.4 and $5.1 \mathrm{mg} \mathrm{dm}^{-3}$, and $\mathrm{S}$ of 6.0 and $4.0 \mathrm{mg} \mathrm{dm}^{-3}$. Exchangeable potassium $\mathrm{K}^{+}$, calcium $\left(\mathrm{Ca}^{+2}\right)$, magnesium $\left(\mathrm{Mg}^{+2}\right)$, and $\mathrm{Al}^{+3}$, cation exchange capacity (CEC), and $\mathrm{H}+\mathrm{Al}$ (total acidity $\mathrm{pH} 7.0$ ) for the topsoil $(0.00-0.20 \mathrm{~m})$ and subsoil $(0.20-0.40 \mathrm{~m})$ were 1.7 and $1.0,17$ and $12.5,6.15$ and $4.9,1.3$ and 2.8, 53.9 and 49.0, and 29.3 and 30.6 molc dm ${ }^{-3}$, respectively. Base saturation for the topsoil $(0.00-0.20 \mathrm{~m})$ and subsoil $(0.20-0.40 \mathrm{~m})$ was 46.1 and $37.6 \%$, respectively. Sand, silt, and clay contents for the topsoil $(0.00-0.20 \mathrm{~m})$ and subsoil $(0.20-0.40 \mathrm{~m})$ were 693 and 677,43 and 34, and 264 and $289 \mathrm{~g}$ $\mathrm{kg}^{-1}$, respectively.

The following characteristics were analyzed: soil $\mathrm{pH}$ in $0.01 \mathrm{~mol} \mathrm{~L}^{-1} \mathrm{CaCl}_{2}, \mathrm{SOM}$ (soil organic matter) by the colorimetric method, $\mathrm{P}$ from extraction by ion exchange resin and determination by colorimetry (Raij et al. 2001), S by $0.5 \mathrm{~mol} \mathrm{~L}^{-1} \mathrm{NH}_{4} \mathrm{OAc}$ in $0.25 \mathrm{~mol} \mathrm{~L}^{-1} \mathrm{HOAc}$ (Vitti 1988), $\mathrm{K}$ from extraction by ion exchange resin and determination by flame photometry (Raij et al. 2001), Ca and $\mathrm{Mg}$ from extraction by ion exchange resin and determination by atomic absorption spectrometry (Raij et al. 2001), $\mathrm{H}+\mathrm{Al}$ (total acidity at $\mathrm{pH}$ 7.0) from determination by a potentiometer in SMPbuffer solution (Raij et al. 2001), Al by $1 \mathrm{~mol} \mathrm{~L}^{-1} \mathrm{KCl}$ (potassium chloridye) (Raij et al. 2001), and Si from extraction by $0.5 \mathrm{~mol} \mathrm{~L}-1$ acetic acid and determination by a spectrophotometer at $660 \mathrm{~nm}$ (Korndörfer et al. 1999). 
A randomized block experimental design was used with four replications. The experiment consisted of six treatments: 1 - control (without application of amendments), 2 - gypsum $\left(1700 \mathrm{~kg} \mathrm{ha}^{-1}\right), 3$ - dolomitic limestone $\left(1800 \mathrm{~kg} \mathrm{ha}^{-1}\right), 4$ - silicate $\left(1700 \mathrm{~kg} \mathrm{ha}^{-1}\right), 5$ - dolomitic limestone $\left(1800 \mathrm{~kg} \mathrm{ha}^{-1}\right)+$ gypsum $\left(1700 \mathrm{~kg} \mathrm{ha}^{-1}\right)$, and 6 - silicate $\left(1700 \mathrm{~kg} \mathrm{ha}^{-1}\right)+$ gypsum $(1700 \mathrm{~kg}$ $\left.\mathrm{ha}^{-1}\right)$. Each sugarcane plot consisted of eight rows of $12 \mathrm{~m}$ length, spaced at $1.4 \mathrm{~m}$.

Dolomitic limestone composition was $40 \% \mathrm{CaO}, 12.0 \% \mathrm{MgO}$, and $85 \%$ effective calcium carbonate equivalence (ECCE). Calcium-magnesium silicate composition was $39.8 \% \mathrm{CaO}, 12.0 \% \mathrm{MgO}$, $23 \% \mathrm{SiO}_{2}$, and $88 \%$ effective Calcium carbonate equivalence (ECCE). The composition of gypsum $\left(\mathrm{CaSO}_{4} \cdot 2 \mathrm{H}_{2} \mathrm{O}\right)$, a by-product obtained from a Brazilian phosphoric acid industry, was $20 \% \mathrm{Ca}, 16 \%$ $\mathrm{S}$, and a small residue of $0.1 \% \mathrm{P}$ and $\mathrm{F}$.

The dolomitic limestone rate (LR) and silicate rate (SR) were calculated so as to increase base saturation in the soil $(0.00-0.40 \mathrm{~m})$ to $60 \%$, according to Spironello et al. (1996). Thus, the soil chemical characteristics determined in the topsoil $(0.00-0.20 \mathrm{~m})$ and the result obtained from the amount of dolomitic limestone and silicate are multiplied by two (Spironello et al. 1996).

The gypsum rate (GR) was calculated by multiplying the clay content in the $0.20-0.40 \mathrm{~m}$ soil layer for six according to Spironello et al. (1996).

Thus, the $\mathrm{Ca}-\mathrm{Mg}$ silicate and dolomite limestone application rates were defined as the control $\left(0 \mathrm{~kg} \mathrm{ha}^{-1}\right)$, half the recommended rate $\left(850 \mathrm{~kg} \mathrm{ha}^{-1}\right.$ and $\left.900 \mathrm{~kg} \mathrm{ha}^{-1}\right)$, the recommended rate $\left(1,700 \mathrm{~kg} \mathrm{ha}^{-1}\right.$ and $\left.1,800 \mathrm{~kg} \mathrm{ha}^{-1}\right)$, and double the recommended rate $\left(3,400 \mathrm{~kg} \mathrm{ha}^{-1}\right.$ and $3600 \mathrm{~kg}$ $\left.\mathrm{ha}^{-1}\right)$, respectively. The recommended rate for gypsum was $1800 \mathrm{~kg} \mathrm{ha}^{-1}$. Before application of the products, silicate or limestone was mixed with gypsum, according to the treatments, and they were packed in plastic bags. Before application of the products, lime and gypsum, and silicate and gypsum were mixed, according to the treatments, and they were packed in plastic bags.

Products were surface applied on the unburnt sugarcane residue layer $\left(12.2\right.$ ton $\left.\mathrm{ha}^{-1}\right)$ without soil incorporation, according to the treatments. Fertilizer at the rate of $70 \mathrm{~kg} \mathrm{ha}^{-1}$ of $\mathrm{N}$ in the form of ammonium nitrate and $80 \mathrm{~kg} \mathrm{ha}^{-1}$ of $\mathrm{K}_{2} \mathrm{O}$ in the form of potassium chloride was applied on the sugar cane ratoon through topdressing.

After 12 months, the experiment was harvested and soil samples were taken at the depths of 0.00 $0.05,0.05-0.10,0.10-0.20,0.20-0.40$, and $0.40-0.60 \mathrm{~m}$ in all plots. Seven subsamples were taken at random between the rows in each plot and combined in one composite sample. Soil samples were chemically analyzed for $\mathrm{pH}, \mathrm{OM}, \mathrm{H}+\mathrm{Al}$, and $\mathrm{P}$, exchangeable $\mathrm{Al}, \mathrm{Ca}, \mathrm{Mg}$, and $\mathrm{K}$ (Raij et al. 2001) and $\mathrm{S}$ (Vitti 1988). Using the results of exchangeable bases and total acidity at $\mathrm{pH} 7.0(\mathrm{H}+\mathrm{Al})$, base saturation values were calculated (Raij et al. 2001).

Stalk yield at harvest was determined in the four central rows, with two rows of plants being used for technological measurements (sugar concentration, purity, fiber, and reducing sugar). One meter was established at random in the two rows of plants, from which the stalks were collected, topped at apical bud height, defoliated, and then taken to the sugarcane technology laboratory at the São Luiz Sugar Mill to be processed according to the methodology defined by the sucrose-content sugarcane payment system, in accordance with Consecana's semiannual updates for technological evaluations described in Fernandes (2011), considering the total reducing sugars parameter for sugarcane. Using the results of stalk yield and sugar concentration, sugar yield values were calculated and, using the results of fiber and stalk yield, bagasse values were calculated at 50\% moisture. For economic analysis, the costs and income of sugarcane producers that delivered their production (stalks and post-harvest residue) to industry in the region of Piracicaba, SP, was considered. Production costs for sugarcane were determined for the Piracicaba region, SP. Trash yield was calculated considering $140 \mathrm{~kg}$ of trash per Mg of stalk (Hassuani, Leal, and Macedo 2005) and considering 60\% collection from the soil surface. The cost of selling sugarcane trash, based on information from producers, was calculated at $\mathrm{U} \$ 38.00 \mathrm{Mg}^{-1}$ for collection and transport, considering a distance of $20 \mathrm{~km}$ to the sugar mill.

Data were subjected to ANOVA using SAS (SAS Institute 1997). The treatments were compared by Fisher's protected LSD test at the 0.05 probability level $(\mathrm{p}<0.05)$. 
Table 1. Values of $\mathrm{pH}, \mathrm{H}+\mathrm{Al}$ (total acidity $\mathrm{pH} 7.0)$, exchangeable $\mathrm{Al}_{3}{ }^{+}\left(\mathrm{Al}_{\mathrm{ex}}\right)$, and $\mathrm{m} \%\left(\mathrm{Al}_{3}{ }^{+}\right.$saturation) of soil samples taken 12 months after surface application of gypsum, dolomitic lime, calcium-magnesium silicate, dolomitic lime associated with gypsum, and calcium-magnesium silicate associated with gypsum in green sugarcane, and ANOVA significance at five soil depths in Pirassununga, São Paulo, Brazil.

\begin{tabular}{|c|c|c|c|c|c|c|}
\hline Treatments† & $\mathrm{pH}$ & $\mathrm{H}+\mathrm{Al}$ & $\mathrm{Al}_{\mathrm{ex}}$ & $\mathrm{m} \%$ & $\mathrm{~S}-\mathrm{SO}_{4}{ }^{-2}$ & $\mathrm{Si}$ \\
\hline & $\left(\mathrm{CaCl}_{2}\right)$ & $-\mathrm{mmol}_{\mathrm{c}} \mathrm{dm}^{-3}$ & -- & $\%$ & $-m$ & $3-$ \\
\hline \multicolumn{7}{|l|}{ depth: $0.0-0.05 \mathrm{~m}$} \\
\hline Control & $4.9 \mathrm{~b} \neq$ & $30.8 a$ & $1.5 a$ & $5.2 \mathrm{a}$ & $5.8 \mathrm{~b}$ & $6.2 \mathrm{c}$ \\
\hline Gypsum & $4.9 \mathrm{~b}$ & $21.8 \mathrm{~b}$ & $1.1 \mathrm{~b}$ & $3.9 \mathrm{~b}$ & $8.3 b$ & $11.7 \mathrm{~b}$ \\
\hline Lime & $5.9 a$ & $18.4 b$ & $1.2 \mathrm{~b}$ & $2.3 \mathrm{bc}$ & $9.4 b$ & $9.9 \mathrm{~b}$ \\
\hline Silicate & $6.0 \mathrm{a}$ & $15.1 \mathrm{~b}$ & $1.1 \mathrm{~b}$ & $1.1 \mathrm{c}$ & $6.7 \mathrm{~b}$ & $15.6 a$ \\
\hline Lime + Gypsum & $6.0 \mathrm{a}$ & $17.7 \mathrm{~b}$ & $1.0 \mathrm{~b}$ & $2.6 \mathrm{bc}$ & $15.0 \mathrm{a}$ & $11.7 \mathrm{~b}$ \\
\hline \multirow[t]{3}{*}{ Silicate + Gypsum } & $6.1 \mathrm{a}$ & $15.7 \mathrm{~b}$ & $0.8 \mathrm{~b}$ & $3.1 \mathrm{~b}$ & $14.9 \mathrm{a}$ & $15.6 \mathrm{a}$ \\
\hline & \multicolumn{6}{|c|}{ ANOVA (F probability) } \\
\hline & $<0.001$ & $<0.001$ & \multicolumn{2}{|c|}{ depth: $0.05-0.10 \mathrm{~m}$} & $<0.001$ & $<0.001$ \\
\hline Control & $4.9 \mathrm{~b}$ & $29.5 a$ & $1.6 a$ & $6.4 a$ & $4.6 c$ & $5.7 \mathrm{~b}$ \\
\hline Gypsum & $4.9 b$ & $28.4 a b$ & $1.2 \mathrm{ab}$ & $4.6 a b$ & $7.8 \mathrm{c}$ & $5.7 \mathrm{~b}$ \\
\hline Lime & $5.4 a$ & $22.8 b c$ & $1.3 a b$ & $3.4 a b$ & $5.4 c$ & $12.9 a$ \\
\hline Silicate & $5.6 a$ & $21.5 b c$ & $1.2 \mathrm{ab}$ & $2.2 \mathrm{~b}$ & $7.4 c$ & $13.2 a$ \\
\hline Lime + Gypsum & $5.6 a$ & $20.6 c$ & $1.0 \mathrm{~b}$ & $2.0 \mathrm{~b}$ & $38.3 a$ & $12.9 \mathrm{a}$ \\
\hline \multirow{3}{*}{ Silicate + Gypsum } & $5.7 \mathrm{a}$ & $17.3 d$ & $0.9 \mathrm{~b}$ & $2.0 \mathrm{~b}$ & $15.1 \mathrm{~b}$ & $13.2 \mathrm{a}$ \\
\hline & \multicolumn{6}{|c|}{ ANOVA (F probability) } \\
\hline & $<0.001$ & $<0.001$ & $\begin{array}{r}<0.001 \\
\text { depth: }\end{array}$ & $\begin{array}{l}<0.001 \\
0 \mathrm{~m}\end{array}$ & $<0.001$ & $<0.001$ \\
\hline Control & $4.9 \mathrm{~b}$ & $27.1 \mathrm{a}$ & $1.5 a$ & $6.1 a$ & $4.1 d$ & $5.7 \mathrm{c}$ \\
\hline Gypsum & $4.9 \mathrm{~b}$ & $26.7 a$ & $1.0 \mathrm{~b}$ & $3.9 \mathrm{~b}$ & $11.0 \mathrm{c}$ & $6.3 c$ \\
\hline Lime & $5.3 a$ & $24.5 \mathrm{ab}$ & $1.3 \mathrm{ab}$ & $3.5 b$ & $6.4 d$ & $7.8 \mathrm{~b}$ \\
\hline Silicate & $5.4 a$ & $22.6 b$ & $1.0 \mathrm{~b}$ & $3.7 \mathrm{~b}$ & $11.7 \mathrm{c}$ & $10.1 \mathrm{a}$ \\
\hline Lime + Gypsum & $5.4 a$ & $23.2 b$ & $0.8 \mathrm{~b}$ & $2.7 \mathrm{bc}$ & $40.7 a$ & $7.9 \mathrm{~b}$ \\
\hline \multirow[t]{3}{*}{ Silicate + Gypsum } & $5.5 a$ & $22.1 b$ & $0.8 \mathrm{~b}$ & $1.8 \mathrm{c}$ & $19.6 \mathrm{~b}$ & $10.1 \mathrm{a}$ \\
\hline & \multicolumn{6}{|c|}{ ANOVA (F probability) } \\
\hline & $<0.001$ & \multicolumn{4}{|c|}{ depth: $0.20-0.40 \mathrm{~m}$} & $<0.001$ \\
\hline Control & $4.6 \mathrm{~b}$ & $30.3 a$ & $2.9 \mathrm{a}$ & $14.2 \mathrm{a}$ & $6.2 d$ & $5.7 c$ \\
\hline Gypsum & $4.7 \mathrm{~b}$ & $29.6 a$ & $1.9 \mathrm{~b}$ & $8.7 \mathrm{~b}$ & $28.4 b$ & $7.0 \mathrm{~b}$ \\
\hline Lime & $5.0 a$ & $28.2 \mathrm{ab}$ & $2.3 b$ & $7.7 c$ & $8.6 \mathrm{~cd}$ & $6.6 b$ \\
\hline Silicate & $5.1 a$ & 26.9ab & $1.8 \mathrm{~b}$ & $8.4 b$ & $10.8 c$ & $9.1 \mathrm{a}$ \\
\hline Lime + Gypsum & $5.0 a$ & $26.7 a b$ & $1.4 \mathrm{c}$ & $5.7 c$ & $46.6 a$ & $7.0 \mathrm{~b}$ \\
\hline \multirow[t]{3}{*}{ Silicate + Gypsum } & $5.1 \mathrm{a}$ & $25.1 \mathrm{~b}$ & $1.2 \mathrm{C}$ & $3.7 d$ & $46.9 a$ & $9.1 \mathrm{a}$ \\
\hline & \multicolumn{6}{|c|}{ ANOVA (F probability) } \\
\hline & \multicolumn{6}{|c|}{ depth: $0.40-0.60 \mathrm{~m}$} \\
\hline Control & $4.3 \mathrm{~b}$ & $35.9 a$ & $4.5 \mathrm{a}$ & $27.6 a$ & $14.9 c$ & $5.6 c$ \\
\hline Gypsum & $4.4 b$ & 33.7ab & $2.4 \mathrm{~b}$ & $12.7 \mathrm{bc}$ & $51.7 a$ & $6.9 \mathrm{ab}$ \\
\hline Lime & $4.6 a$ & $31.1 \mathrm{ab}$ & $3.7 a b$ & $18.5 b$ & $19.4 b$ & $6.5 b$ \\
\hline Silicate & $4.7 a$ & $30.2 b$ & $3.5 \mathrm{ab}$ & $16.0 \mathrm{~b}$ & $26.3 a b$ & $7.7 \mathrm{a}$ \\
\hline Lime + Gypsum & $4.7 a$ & $30.8 b$ & $2.5 \mathrm{~b}$ & $12.2 \mathrm{bc}$ & $47.2 \mathrm{ab}$ & $6.5 b$ \\
\hline \multirow[t]{3}{*}{ Silicate + Gypsum } & $4.7 a$ & $29.3 b$ & $2.4 \mathrm{~b}$ & $9.3 c$ & $52.4 a$ & $7.7 \mathrm{a}$ \\
\hline & \multicolumn{6}{|c|}{ ANOVA (F probability) } \\
\hline & 0.047 & 0.033 & $<0.001$ & $<0.001$ & $<0.001$ & $<0.001$ \\
\hline
\end{tabular}

\section{Results and discussion}

According to Table 1, at 12 months after application, both limestone and silicate sources (in association with gypsum or not) increased soil $\mathrm{pH}$ up to the $0.6 \mathrm{~m}$ depth, without significant differences between them.

Gypsum, for its part, did not alter soil $\mathrm{pH}$, but it reduced potential acidity $(\mathrm{H}+\mathrm{Al})$ in the topsoil layer $(0.00-0.05 \mathrm{~m})$ and $\mathrm{Al}$ and $\mathrm{m} \%$ in all the layers, except for $0.05-0.10 \mathrm{~m}$. Raij (2008) has suggested some hypotheses to explain the mechanism involved. One would be the release of $\mathrm{OH}^{-}$ 
by $\mathrm{SO}_{4}{ }^{2-}$ through ligand exchange, with the formation of hydroxylated aluminum structures, a mechanism called the "self-liming" effect. The precipitation of aluminum from formation of minerals has also been indicated. Another possibility would be leaching of aluminum along with gypsum, which may in part be favored by the formation of ion pairs or complexes, such as $\mathrm{AlSO}_{4}{ }^{+}$or aluminum fluoride.

For $\mathrm{S}_{-} \mathrm{SO}_{4}{ }^{-2}$, gypsum application did not lead to significant increases in the surface layers (up to $0.10 \mathrm{~m}$ ). Below these layers, significant increases were observed in the $\mathrm{S}_{-} \mathrm{SO}_{4}{ }^{-2}$ contents, with a greater increase observed in the $0.40-0.60 \mathrm{~m}$ layer, indicating the high mobility of this anion in the soil.

Application of limestone alone led to a small increase in the $\mathrm{S}_{-} \mathrm{SO}_{4}{ }^{-2}$ contents as of $0.20 \mathrm{~m}$. For application of silicate alone, increase in the $\mathrm{S}_{-} \mathrm{SO}_{4}{ }^{-2}$ contents occurred as of $0.10 \mathrm{~m}$, but the greatest increase in relation to the control occurred in the deepest layer $(0.40-0.60 \mathrm{~m})$. An increase in $\mathrm{pH}$ occurs through application of silicate and liming (Table 1), which promotes an increase in availability of $\mathrm{SO}_{4}{ }^{-2}$ both by reducing its adsorption (Pozza et al. 2007; Rampim, Lana, and Frandoloso 2013) and by increasing release of the adsorbed quantity. Since it has greater solubility, silicate raises soil $\mathrm{pH}$ more quickly than limestone, making this anion more susceptible to displacement to deeper layers.

The application of limestone combined with gypsum, and silicate combined with gypsum led to the greatest $\mathrm{S}_{-} \mathrm{SO}_{4}{ }^{-2}$ contents in all the layers evaluated; however, limestone in association with gypsum led to greater increases in the $\mathrm{S}_{-} \mathrm{SO}_{4}{ }^{-2}$ contents in the $0.05-0.10$ and $0.10-0-20 \mathrm{~m}$ layers in relation to silicate. In the same way as observed for application of limestone alone, it is possible that application of silicate combined with gypsum more quickly raised the $\mathrm{S}_{-} \mathrm{SO}_{4}{ }^{-2}$ contents available in the soil and, therefore, they moved to deeper soil layers than the layers evaluated. This would not have occurred for limestone since its dissolution is slower.

An increase in Si contents was observed in the surface layer $(0.00-0.05 \mathrm{~m})$ and deeper layers $(0.20-0.40 \mathrm{~m}$ and $0.40-0.60 \mathrm{~m})$ when gypsum was applied. With the application of gypsum, sulfate concentrations in the soil were increased, which may have displaced silicate from the adsorption sites, increasing Si availability.

The application of limestone alone or combined with gypsum also led to an increase in Si contents. However, the treatments with application of silicate alone or combined with gypsum were those that brought about the greatest increases in the Si contents. The increase in Si contents in the soil is due to the presence of $\mathrm{Si}$ in the silicate $\left(23 \% \mathrm{SiO}_{2}\right)$. Furthermore, the solubility of $\mathrm{Si}$ increases along with an increase in $\mathrm{pH}$ (Oliveira, Korndorfer, and Pereira 2007).

Application of gypsum alone brought about a significant increase in Ca contents (Table 2) only in the $0.40-0.60 \mathrm{~m}$ layer. The application of gypsum led to small reductions of $\mathrm{Mg}$ contents in the $0.00-$ 0.05 and $0.05-0.10 \mathrm{~m}$ surface layers and small increases in the contents below $0.20 \mathrm{~m}$. For $\mathrm{K}$, there was a reduction in the contents up to $0.40 \mathrm{~m}$ and a large increase in the $\mathrm{K}$ contents in the deepest layer (0.40-0.60 m). According to Rampim and Lana (2015) the use of gypsum causes leaching of $\mathrm{K}^{+}$ ions, due to the formation of ion pairs with $\mathrm{SO}_{4}{ }^{2-}$ ions from the dissociation of gypsum in the soil solution. The binding energy of the $\mathrm{Ca}, \mathrm{Mg}$, and $\mathrm{K}$ exchangeable cations to the soil colloids depends on the valence and the size of the hydrated ion, such that in well-drained soils, the quantities of leached $\mathrm{K}$ are relatively greater than those of the bivalent cations.

The application of gypsum did not lead to an increase in base saturation in the surface layers (up to $0.20 \mathrm{~m}$ ), but below that, it led to small increases, probably caused by the ability of $\mathrm{S}_{-} \mathrm{SO}_{4}{ }^{-2}$ to displace cations such as $\mathrm{Ca}, \mathrm{Mg}$, and $\mathrm{K}$ to deeper layers. In contrast, the application of limestone and silicate alone or in association with gypsum led to increases in base saturation in all the layers, but the most expressive increases were seen in the surface layers (up to $0.10 \mathrm{~m}$ ). The application of limestone alone led to smaller increases in base saturation (BS) than the application of silicate, up to a depth of $0.20 \mathrm{~m}$.

The application of limestone combined with gypsum also led to smaller increases in BS than the application of silicate combined with gypsum in the $0.0-0.05,0.10-0.20$, and $0.20-0.40 \mathrm{~m}$ layers, 
Table 2. Values of exchangeable $\mathrm{Ca}, \mathrm{Mg}$, and $\mathrm{K}$, base saturation, $\mathrm{P}$, and organic matter of soil samples taken 12 months after surface application of gypsum, dolomitic lime, calcium-magnesium silicate, dolomitic lime associated with gypsum, and calciummagnesium silicate associated with gypsum in green sugarcane, and ANOVA significance at five soil depths in Pirassununga, São Paulo, Brazil.

\begin{tabular}{|c|c|c|c|c|c|c|}
\hline Treatments & $\mathrm{Ca}_{\mathrm{ex}}$ & $\mathrm{Mg}_{\mathrm{ex}}$ & $\mathrm{K}_{\mathrm{ex}}$ & BS & $\mathrm{P}$ & $\mathrm{OM}$ \\
\hline & \multicolumn{3}{|c|}{-—- $\mathrm{mmol}_{\mathrm{c}} \mathrm{dm}^{-3}-\square-\square$} & $\%$ & $\mathrm{mg} \mathrm{dm}^{-3}$ & $\mathrm{~g} \mathrm{dm}^{-3}$ \\
\hline \multicolumn{7}{|l|}{ depth: $0.0-0.05 \mathrm{~m}$} \\
\hline Control & $18.1 \mathrm{~d} \neq$ & $8.4 b c$ & $0.78 a$ & $47.0 \mathrm{c}$ & $3.6 \mathrm{c}$ & $23.4 a$ \\
\hline Gypsum & $21.0 \mathrm{~d}$ & $5.9 c$ & $0.53 b$ & $55.7 c$ & $6.4 b$ & $26.3 a$ \\
\hline Lime & $36.6 c$ & $13.2 b$ & $0.55 b$ & $76.9 b$ & $11.7 a$ & $27.0 a$ \\
\hline Silicate & $64.7 \mathrm{a}$ & $35.1 \mathrm{a}$ & $0.51 b$ & $84.5 \mathrm{a}$ & $14.1 \mathrm{a}$ & $28.2 \mathrm{a}$ \\
\hline Lime + Gypsum & $44.5 b$ & $8.8 b c$ & $0.26 \mathrm{~d}$ & $77.3 b$ & $12.7 \mathrm{a}$ & $27.9 a$ \\
\hline \multirow{3}{*}{ Silicate + Gypsum } & $64.9 a$ & $34.2 \mathrm{a}$ & $0.40 c$ & $84.9 a$ & $16.2 \mathrm{a}$ & $26.6 a$ \\
\hline & \multicolumn{6}{|c|}{ ANOVA (F probability) } \\
\hline & $<0.001$ & $<0.001$ & $<0.001$ & $<0.001$ & $<0.001$ & 0.357 \\
\hline Treatments & \multicolumn{6}{|c|}{ depth: 0.05-0.10 m } \\
\hline Control & $16.2 \mathrm{c}$ & $6.4 \mathrm{de}$ & $0.61 a$ & $44.0 \mathrm{c}$ & $2.4 \mathrm{~d}$ & $23.4 a$ \\
\hline Gypsum & $18.9 c$ & $5.4 \mathrm{e}$ & $0.34 c$ & $46.5 c$ & $4.5 c$ & $24.4 a$ \\
\hline Lime & $26.7 \mathrm{~b}$ & $9.9 c$ & $0.41 b$ & $61.9 b$ & $7.0 \mathrm{~b}$ & $25.0 \mathrm{a}$ \\
\hline Silicate & $31.9 a b$ & $20.5 a$ & $0.32 c$ & $71.0 a$ & $6.4 b$ & $25.3 a$ \\
\hline Lime + Gypsum & $35.9 a$ & $7.5 \mathrm{~d}$ & $0.28 \mathrm{c}$ & $68.0 a$ & $7.0 \mathrm{~b}$ & $25.2 \mathrm{a}$ \\
\hline \multirow[t]{3}{*}{ Silicate + Gypsum } & $34.8 \mathrm{a}$ & $14.6 \mathrm{~b}$ & $0.16 \mathrm{~d}$ & $74.1 \mathrm{a}$ & $9.1 \mathrm{a}$ & $26.0 \mathrm{a}$ \\
\hline & \multicolumn{6}{|c|}{ ANOVA (F probability) } \\
\hline & $<0.001$ & $<0.001$ & $<0.001$ & $<0.001$ & $<0.001$ & 0.222 \\
\hline Treatments & \multicolumn{6}{|c|}{ depth: $0.10-0.20 \mathrm{~m}$} \\
\hline Control & $17.5 \mathrm{~d}$ & $5.3 \mathrm{~d}$ & $0.35 a$ & $46.1 d$ & $2.4 c$ & $21.8 \mathrm{a}$ \\
\hline Gypsum & $18.5 \mathrm{~d}$ & $6.0 \mathrm{~d}$ & $0.21 b$ & $48.1 d$ & $3.8 \mathrm{~b}$ & $22.5 a$ \\
\hline Lime & $20.2 c$ & $7.5 c$ & $0.22 \mathrm{~b}$ & $53.3 c$ & $5.1 \mathrm{ab}$ & $23.1 \mathrm{a}$ \\
\hline Silicate & $24.1 b$ & $9.4 b$ & $0.22 b$ & $59.9 b$ & $5.8 \mathrm{a}$ & $23.2 a$ \\
\hline Lime + Gypsum & $20.8 a$ & 7.7c & $0.12 \mathrm{c}$ & $55.2 \mathrm{c}$ & $5.9 a$ & $22.6 a$ \\
\hline \multirow[t]{3}{*}{ Silicate + Gypsum } & $31.0 a$ & $13.3 a$ & $0.08 d$ & $66.8 \mathrm{a}$ & $6.3 a$ & $24.4 a$ \\
\hline & \multicolumn{6}{|c|}{ ANOVA ( $F$ probability) } \\
\hline & $<0.001$ & $<0.001$ & $<0.001$ & $<0.001$ & $<0.001$ & 0.381 \\
\hline Treatments & \multicolumn{6}{|c|}{ depth: $0.20-0.40 \mathrm{~m}$} \\
\hline Control & $12.4 c$ & $4.9 \mathrm{~d}$ & $0.19 a$ & $36.6 d$ & $1.6 c$ & $19.7 a$ \\
\hline Gypsum & $14.2 \mathrm{bc}$ & $5.7 c$ & $0.12 \mathrm{~b}$ & $40.3 c$ & $3.2 \mathrm{ab}$ & $21.1 \mathrm{a}$ \\
\hline Lime & $15.9 \mathrm{~b}$ & $5.6 c$ & $0.13 b$ & $43.4 b c$ & $2.8 b$ & $22.9 a$ \\
\hline Silicate & $17.6 a b$ & $7.5 b$ & $0.14 b$ & $48.4 \mathrm{~b}$ & $2.7 \mathrm{~b}$ & $21.7 a$ \\
\hline Lime + Gypsum & $16.0 \mathrm{~b}$ & $7.0 \mathrm{~b}$ & $0.08 c$ & $47.9 \mathrm{~b}$ & $3.4 a b$ & $23.1 \mathrm{a}$ \\
\hline \multirow[t]{3}{*}{ Silicate + Gypsum } & $20.3 a$ & $10.7 a$ & $0.06 c$ & $53.8 \mathrm{a}$ & $3.9 a$ & $22.3 a$ \\
\hline & \multicolumn{6}{|c|}{ ANOVA (F probability) } \\
\hline & $<0.001$ & $<0.001$ & $<0.001$ & $<0.001$ & $<0.001$ & 0.480 \\
\hline Treatments & \multicolumn{6}{|c|}{ depth: $0.40-0.60 \mathrm{~m}$} \\
\hline Control & $8.4 c$ & $3.2 \mathrm{c}$ & $0.23 b$ & $24.8 c$ & $1.1 b$ & $19.8 a$ \\
\hline Gypsum & $11.6 \mathrm{~b}$ & $4.2 b$ & $0.64 a$ & $32.8 \mathrm{~b}$ & $2.3 a b$ & $21.1 \mathrm{a}$ \\
\hline Lime & $11.2 \mathrm{~b}$ & $4.1 \mathrm{~b}$ & $0.09 c$ & $33.1 b$ & $2.1 \mathrm{ab}$ & $19.8 \mathrm{a}$ \\
\hline Silicate & $13.0 \mathrm{ab}$ & $6.3 a b$ & $0.06 c$ & $39.1 a b$ & $1.9 a b$ & $20.8 a$ \\
\hline Lime + Gypsum & $13.0 \mathrm{ab}$ & $4.9 b$ & $0.13 c$ & $38.1 \mathrm{ab}$ & $3.0 \mathrm{a}$ & $22.0 a$ \\
\hline \multirow[t]{3}{*}{ Silicate + Gypsum } & $15.2 \mathrm{a}$ & $8.0 \mathrm{a}$ & $0.09 c$ & $43.1 \mathrm{a}$ & $3.7 a$ & $20.8 \mathrm{a}$ \\
\hline & \multicolumn{6}{|c|}{ ANOVA (F probability) } \\
\hline & $<0.001$ & $<0.001$ & $<0.001$ & $<0.001$ & $<0.001$ & 0.265 \\
\hline
\end{tabular}

† Control (without application of any of the products studied), Gypsum (1700 kg ha $\left.{ }^{-1}\right)$, Silicate (1700 kg ha $\left.{ }^{-1}\right)$, Lime $\left(1800 \mathrm{~kg}^{-1}\right.$ $\left.\mathrm{ha}^{-1}\right)$, Silicate + Gypsum $\left(1700 \mathrm{~kg} \mathrm{ha}^{-1}+1700 \mathrm{~kg} \mathrm{ha}^{-1}\right)$, and Lime + Gypsum $\left(1800 \mathrm{~kg} \mathrm{ha}^{-1}+1700 \mathrm{~kg} \mathrm{ha}^{-1}\right)$.

₹ Within each variable, values in the columns followed by the same letter are not significantly different at $P \leq 0.05$ according to the LSD test.

indicating that limestone has a slower reaction than silicate. Compared to lime, silicate is more efficient in correcting acidity down through the profile, due to its higher solubility (Deus et al. 2014). As the silicate reaction is faster in the uppermost soil layers, an alkalinization front is formed to correct the acidity of the deeper layers in a shorter period of time. Castro and Crusciol (2013), in an experiment at 18 months after application of silicate on the surface of an Oxisol under no-tillage, 
also observed that products from silicate dissociation reach deeper soil layers, compared to the effects of liming.

It may be observed that the application of silicate and limestone (in association with gypsum or not) led to an increase in $\mathrm{P}$ availability in all the soil layers. Although there was a greater increase in $\mathrm{P}$ availability in some layers from the application of silicate compared to limestone, it is not possible to observe this tendency in all the layers. The use of lime and silicate assisted in desorption of $\mathrm{P}$ for, according to Arruda, Lana, and Pereira (2015), the increase in $\mathrm{pH}$ led to an increase in the solubility of $\mathrm{Fe}$ and $\mathrm{Al}$ phosphates and an increase in the concentration of $\mathrm{OH}-$ in the soil solution, thus reducing the adsorption of phosphate in the solid phase of the soil. Furthermore, silicate anions are considered as competitors of phosphate for the same adsorption sites in soil such that silicon can displace (desorb) phosphate, or be displaced by it, from the solid phase to the liquid phase (Sandim et al. 2014). Thus, amendment of soil acidity with silicates, in addition to reducing phosphate adsorption, increases $\mathrm{P}$ availability through the additional effect of displacing the $\mathrm{P}$ adsorbed to the solution (Pulz et al. 2008).

Gypsum also led to an increase in P contents in most of the soil layers, though to a lesser degree compared to the application of limestone and silicate. The application of gypsum significantly increased the P levels in the soil throughout the profile. Despite the small amount of $\mathrm{P}$ present in gypsum (1\%), it was able to raise the $\mathrm{P}$ levels by about $1 \mathrm{mg} \mathrm{dm}{ }^{-3}$. Silva, Chien, and Prochnow (2010) also observed an increase in P uptake through the application of gypsum.

For soil organic matter contents, significant differences were not observed from the application of soil acidity amendments and of gypsum. Soil amendment can accelerate mineralization of OM through increasing the $\mathrm{pH}$, reducing the $\mathrm{OM}$ content in the soil (Fuentes, González-Gaitano, and Garcia-Mina 2006). In this study, however, there was no change in the OM content in the soil profile through surface application of lime, silicate, and gypsum, indicating that the change in OM content may take longer or the degree of change in $\mathrm{pH}$ was not sufficient to change the OM content.

The technological parameters of Pol, purity, fiber, and reducing sugar (Table 3) were not influenced by the application of gypsum, limestone, and silicate. For Leite et al. (2008), the application of calcium silicate in the plant row led to an increase only in fiber contents (\%) in sugarcane, but did not have an effect on total recoverable sugar, nor on the contents of Brix, pol, and purity (\%). Crusciol et al. (2014), in a study with surface application of different silicate rates combined with gypsum in ratoon cane, also did not observe an effect from them on the technological parameters. Carvalho et al. (2013) also observed a lack of response from gypsum application in

Table 3. Values of Pol, purity, fiber, reducing sugar (RS), stalk and sugar yield, trash (post-harvest residues), bagasse, and energy production, taken 12 months after surface application of gypsum, dolomitic lime, calcium-magnesium silicate, dolomitic lime associated with gypsum, and calcium-magnesium silicate associated with gypsum in green sugarcane, and ANOVA significance in Pirassununga, São Paulo, Brazil.

\begin{tabular}{|c|c|c|c|c|c|c|c|c|c|}
\hline Treatments & Pol & Purity & Fiber & RS & Stalk & Sugar & Trash & Bagasse & Energy \\
\hline & \multicolumn{4}{|c|}{-二——--\%————-- } & \multicolumn{4}{|c|}{ ——————-Mg ha ${ }^{-1}$-—————- } & MWh \\
\hline Control & 17.8ał & $91.6 a$ & $12.5 a$ & $0.41 a$ & $66.1 c$ & $11.8 \mathrm{c}$ & $5.55 c$ & $8.26 c$ & $68.32 c$ \\
\hline Gypsum & $18.2 \mathrm{a}$ & $92.0 \mathrm{a}$ & $12.5 a$ & $0.40 \mathrm{a}$ & $76.0 \mathrm{~b}$ & $13.8 b$ & $6.38 b$ & $9.50 \mathrm{~b}$ & $78.56 \mathrm{~b}$ \\
\hline Lime & $18.0 \mathrm{a}$ & $92.1 \mathrm{a}$ & $12.5 a$ & $0.40 \mathrm{a}$ & 79.5ab & 14.3ab & $6.68 a b$ & $9.94 a b$ & 82.22ab \\
\hline Silicate & $17.8 \mathrm{a}$ & $92.8 \mathrm{a}$ & 13.0a & $0.40 \mathrm{a}$ & $80.2 a b$ & 14.3ab & $6.74 a b$ & 10.43ab & 84.94ab \\
\hline Lime + Gypsum & $18.0 \mathrm{a}$ & $91.7 a$ & $12.5 \mathrm{a}$ & $0.41 a$ & 81.8ab & 14.7ab & $6.87 a b$ & 10.22ab & 84.55ab \\
\hline Silicate + Gypsum & $17.7 a$ & $91.0 a$ & $12.7 a$ & $0.44 a$ & 87.0a & $15.4 a$ & $7.31 a$ & $11.05 a$ & $90.83 a$ \\
\hline ANOVA (F probability) & 0.416 & 0.593 & 0.409 & 0.662 & $<0.001$ & $<0.001$ & $<0.001$ & $<0.001$ & $<0.001$ \\
\hline
\end{tabular}

† Control (without application of any of the products studied), Gypsum (1700 kg ha $\left.{ }^{-1}\right)$, Silicate (1700 kg ha $\left.{ }^{-1}\right)$, Lime $(1800 \mathrm{~kg}$ $\left.\mathrm{ha}^{-1}\right)$, Silicate + Gypsum $\left(1700 \mathrm{~kg} \mathrm{ha}^{-1}+1700 \mathrm{~kg} \mathrm{ha}^{-1}\right)$, and Lime + Gypsum $\left(1800 \mathrm{~kg} \mathrm{ha}^{-1}+1700 \mathrm{~kg} \mathrm{ha}^{-1}\right)$. ‡ Within each variable, values in the columns followed by the same letter are not significantly different at $P \leq 0.05$ according to the LSD test. ${ }^{(4)}$ Trash yield = Stalk yield $\times 0.14$ (140 kg of trash per Mg of stalks (Hassuani, Leal, and Macedo 2005) considering $60 \%$ collection of sugarcane trash. Bagasse yield = fiber $\mathrm{x}$ stalk yield. Considering that $1 \mathrm{Mg}$ of trash has $4.96 \mathrm{MWh}$ of primary energy and $1 \mathrm{Mg}$ of bagasse has 4.94 MWh of primary energy (Hassuani, Leal, and Macedo 2005). $1 \mathrm{MWh}=3,600.00 \mathrm{MJ}$. 
ratoon cane without burning, and indicated that the use of soil amendments does not hurt the quality of raw material for industry.

The application of gypsum alone led to an increase in stalk, sugar, trash, bagasse, and energy yield (Table 4). Improvements in chemical properties (Tables 1 and 2) are probably responsible for an increase in yield when gypsum is applied on ratoon cane. Carvalho et al. (2013) did not find an increase in stalk and sugar yield from surface application of gypsum in ratoon cane. However, corroborating the data in this study, Crusciol et al. (2014), evaluating surface application of gypsum in ratoon cane, also found an increase in stalk and sugar yield.

Application of limestone and silicate alone and limestone with gypsum led to significant increases in stalk, sugar, trash, bagasse, and energy yield in relation to the control; however, they did not differ from application of gypsum alone, nor from application of silicate with gypsum. Corroborating these data, Morelli et al. (1992) concluded that sugarcane yield, over the period of four cuttings, was similar for limestone and for gypsum applied alone, and greater than the control treatment. However, in contrast with the data found here, they observed an increase in stalk yield from the association of limestone and gypsum in relation to application of limestone alone or gypsum alone.

The application of silicate associated with gypsum led to an increase in stalk, sugar, bagasse, trash, and energy yield in relation to application of gypsum and the control treatment; however, it did not differ from the other treatments. Increases were $20.9 \mathrm{Mg} \mathrm{ha}^{-1}$ for stalk yield, $3.6 \mathrm{Mg} \mathrm{ha}^{-1}$ for sugar, $1.76 \mathrm{Mg} \mathrm{ha}^{-1}$ for trash, $2.79 \mathrm{Mg} \mathrm{ha}^{-1}$ for bagasse, and 22.51 MWh of energy in relation to the control treatment. These results are probably associated with the rapid dissolution and correction of acidity and availability of nutrients (Tables 1 and 2) brought about by silicate, in association with the benefits from gypsum. Crusciol et al. (2014), upon applying different rates of silicate combined with gypsum, observed that at the lower rates of silicate, the gypsum led to an increase in stalk and sugar yield, a result that was not repeated at the greater application rates of silicate. According to the authors, these results may be associated with amendment of acidic soil and nutrient availability in the soil profile caused by application of high rates of silicate.

From an economic perspective (Table 4), it may be observed that all the treatments, in spite of leading to an increase in production costs, led to profitability greater than the control treatment already in the first cutting of the sugarcane after surface application. Silicate has the greatest cost per ton applied (U\$ $66.82 \mathrm{Mg}^{-1}$ ), due to the expenses in transport of this soil amendment from the production source to the sugarcane producer, which led to greater profitability for application of limestone alone in relation to silicate alone. However, in spite of the greater cost per ton of silicate, the application of silicate in association with gypsum led to greater profitability than the other

Table 4. Economic analysis surface application of dolomitic lime, calcium-magnesium silicate, dolomitic lime associated with gypsum, and calcium-magnesium silicate associated with gypsum in green sugarcane in Pirassununga, São Paulo, Brazil.

\begin{tabular}{|c|c|c|c|c|c|c|c|c|}
\hline & $\begin{array}{c}\text { Stalk } \\
\text { yield }\end{array}$ & $\operatorname{TRS}^{(1)}$ & Cost of production ${ }^{(2)}$ & Income $^{(3)}$ & $\frac{\text { Trash }}{\text { yield }^{(4)}}$ & $\frac{\text { Trash }}{\text { Cost }^{(5)}}$ & $\frac{\text { Trash }}{\text { Income }^{(6)}}$ & $\mathrm{Net}^{(7)}$ \\
\hline Treatments† & $\overline{\mathrm{Mg} \mathrm{ha}^{-1}}$ & $\overline{\mathrm{kg} \mathrm{Mg}^{-1}}$ & -———-U\$ ha ${ }^{-1}$ & - - - & $\mathrm{Mg} \mathrm{ha}^{-1}$ & - & $-U \$ h^{-1}$ & - \\
\hline Control & 66.1 & 173 & 2353 & -232 & 5.55 & 211 & 78 & -154 \\
\hline Gypsum & 76.0 & 177 & 2469 & 22 & 6.38 & 243 & 89 & 111 \\
\hline Lime & 79.5 & 175 & 2510 & 67 & 6.68 & 254 & 93 & 161 \\
\hline Silicate & 80.2 & 173 & 2518 & 54 & 6.74 & 256 & 94 & 148 \\
\hline Lime + Gypsum & 81.8 & 175 & 2537 & 116 & 6.87 & 261 & 96 & 213 \\
\hline Silicate + Gypsum & 87.0 & 173 & 2598 & 182 & 7.31 & 278 & 102 & 285 \\
\hline
\end{tabular}

(1) TRS: Total Recoverable Sugars, calculated according to Fernandes (2011); (2) Sugarcane Cost of production, Piracicaba Region $\mathrm{SP}$, considering the cost of $\mathrm{U} \$ 1,576.40 \mathrm{ha}^{-1}$ for establishment and cultivation of sugarcane field; and U\$ 11.744 per $\mathrm{Mg}^{-1}$ of stalks produced in regard to cutting, loading, and transportation; and U\$ $42.00 \mathrm{Mg}^{-1}$, U\$ $38.80 \mathrm{Mg}^{-1}$, and U\$ $66.82 \mathrm{Mg}^{-1}$ for gypsum, lime and silicate applied in the field, respectively. Considering $1 \mathrm{U} \$=2.5$ R\$. ${ }^{(3)}$ Income $=$ (Stalk Yield $x$ TRS x U\$ 0.18516 (price paid per $\mathrm{kg}$ of TRS)) - cost of production. ${ }^{(4)}$ Trash yield = Stalk yield $\times 0.14$ (140 kg of trash per Mg of stalks (Hassuani, Leal, and Macedo 2005) considering 60\% collection of sugarcane trash. ${ }^{(5)}$ Trash cost $=U \$ 38.00 \mathrm{Mg}^{-1}$ to collect and transport sugarcane trash, considering a distance of $20 \mathrm{~km}$ to the sugar mill. ${ }^{(6)}$ Trash Income $=U \$ 52.00 \mathrm{Mg}^{-1}$ of trash (price paid for trash) $x$ trash yield - trash cost. ${ }^{(7)}$ Net $=$ Income + Trash Income. 
treatments, increasing profitability by $\mathrm{U} \$ 439.00 \mathrm{ha}^{-1}$ in relation to the control treatment and U\$ $72.00 \mathrm{ha}^{-1}$ in relation to the application of limestone associated with gypsum.

\section{Conclusion}

(1) Surface application of gypsum led to reduction in $\mathrm{Al}$ contents and $\mathrm{Al}$ saturation, and increase in $\mathrm{Mg}^{+2}, \mathrm{Ca}^{+2}, \mathrm{~K}^{+}, \mathrm{S}_{-} \mathrm{SO}_{4}^{-}$, and base saturation in deeper soil layers, as well as increased yield of stalks, sugar, trash (post-harvest residue), bagasse, and energy, and greater profit.

(2) The application of limestone and silicate, alone or in association with gypsum, amended soil acidity and improved fertility throughout the soil profile. It likewise led to an increase in stalk, sugar, trash (post-harvest residue), bagasse, and energy yield.

(3) The application of silicate or limestone, alone or in association with gypsum, increased profitability for producers that supply stalks and post-harvest residue to industry. However, application of silicate in association with gypsum led to the greatest profitability.

\section{Acknowledgments}

The authors would like to thank the Coordination of Improvement of Higher Education Personnel (CAPES) for financial support (PROAP) and the National Council for Scientific and Technological Development (CNPq) for an award for excellence in research to the second author.

\section{ORCID}

Carlos Antonio Costa do Nascimento (D) http://orcid.org/0000-0003-3786-9845

\section{References}

Arruda, E. M., R. M. Q. Lana, and H. S. Pereira. 2015. Phosphorus extracted by mehlichi and anion exchange resin in soils subjected to liming. Bioscience Journal 31:1107-17.

Caires, E., H. Joris, and S. Churka. 2011. Long-term effects of lime and gypsum additions on no-till maize and soybean yield and soil chemical properties in southern Brazil. Soil Use Management 27:45-53.

Caires, E. F., J. C. L. Corrêa, S. Churka, G. Barth, and F. J. Garbuio. 2006. Surface application of lime ameliorates subsoil acidity and improves root growth and yield of wheat in an acid soil under no-till system. Scientia Agricola 63:502-09.

Carvalho, J. M., M. Andreotti, S. Buzetti, and M. Passos. 2013. Unburned ratoon sugarcane yield according to gypsum and vinasse doses. Pesquisa Agropecuária Tropical 43:1-9.

Castro, G. S. A., and C. A. C. Crusciol. 2013. Effects of superficial liming and silicate application on soil fertility and crop yield under rotation. Geoderma 195-96:234-42.

Crusciol, C. A. C., R. Foltran, O. B. Rossato, J. M. McCRAY, and R. Rossetto. 2014. Effects of surface application of calcium-magnesium silicate and gypsum on soil fertility and sugarcane yield. Revista Brasileira De Ciência Do Solo 38:1843-54.

Deus, A. C. F., L. T. Bull, J. C. Correa, and R. L. Villas Boas. 2014. Determination of reactivity rates of silicate particlesize fractions. Revista Ceres 61:265-72.

Fernandes, A. C. 2011. Calculations in the sugarcane agro-industry, 3rd ed. Piracicaba: STAB.

Fuentes, M., G. González-Gaitano, and J. M. Garcia-Mina. 2006. The usefulness of UV-Visible and fluorescence sepectroscopies to study the chemical nature of humic substances from soils and composts. Organic Geochemistry 37:1949-59.

Hassuani, S. J., M. R. L. V. Leal, and I. C. Macedo. 2005. Biomass power generation: Sugar cane bagasse and trash. Piracicaba: PNUD-CTC.

Institute, S. A. S. 1997. SAS/STAT software: Changes and enhancements through release 6.12. Cary: Statistical Analysis System Institute.

Korndörfer, G. H., N. M. Coelho, G. H. Snyder, and C. T. Myzutani. 1999. Evaluation of soil extractants for silicon availability in upland rice. Revista Brasileira de Ciência do Solo 23:101-06. 
Leite, G. M. V., L. A. B. Andrade, J. C. Garcia, and I. A. Anjos. 2008. Effects of sources and dosages of calcium silicate on yeld and quality of sugarcane, cultivar SP80-1816. Ciência e Agrotecnologia 32:1120-25.

Morelli, S. L., A. E. Dalben, J. O. C. Almeida, and J. L. I. Demattê. 1992. Lime and phosphogypsum effects on the productivity of sugarcane and on the chemical properties of a medium texture latosol. Revista Brasileira de Ciência do Solo 16:187-94.

Oliveira, L. A. D., G. H. Korndorfer, and A. C. Pereira. 2007. Silicon accumulation in rice in different rhizosphere ph conditions. Revista Brasileira de Ciência do Solo 31:685-90.

Pozza, A. A. A., N. Curi, E. T. S. Costa, L. R. G. Guilherme, J. J. G. S. M. Marques, and P. E. F. Motta. 2007. Competitive retention and desorption of inorganic anions on natural soil gibbsite. Pesquisa Agropecuária Brasileira 42:1627-33.

Pulz, A. L., C. A. C. Crusciol, L. B. Lemos, and R. P. Soratto. 2008. Silicate and limestone effects on potato nutrition, yield and quality under drought stress. Revista Brasileira De Ciência Do Solo 32:1651-59.

Raij, B. V. 2008. Gypsum in agriculture. Campinas: Agronomic Institute of Campinas.

Raij, B. V., J. C. Andrade, H. Cantarella, and J. A. Quaggio. 2001. Chemical analysis for fertility evaluation of tropical soils. Campinas: Agronomic Institute of Campinas.

Rampim, L., and M. C. Lana. 2015. Ion mobility and base saturation after gypsum application in continuous soybeanwheat cropping system under no-till. Australian Journal of Crop Science 9:468-76.

Rampim, L., M. C. Lana, and J. F. Frandoloso. 2013. Available phosphorus and sulphur, exchangeable aluminum and remaining phosphorus in rhodic eutrudox submitted to gypsum cultivated with wheat and soybean. Semina: Ciências Agrárias 34:1623-38.

Sandim, A. S., L. T. Büll, A. R. Furim, G. S. Lima, and J. L. N. Garcia. 2014. Phosphorus availability in oxidic soils treated with lime and silicate applications. Revista Brasileira De Ciência Do Solo 38:1215-22.

Silva, R. C. D., S. H. Chien, and L. I. Prochnow. 2010. Available phosphorus evaluated by three soil tests in a Brazilian tropical oxisol treated with gypsum. Soil Science 175:233-39.

Soratto, R. P., and C. A. C. Crusciol. 2008. Chemical soil attributes as affected by lime and phosphogypsum surface application in a recently established no-tillage system. Revista Brasileira De Ciência Do Solo 32:675-88.

Spironello, A., B. V. Raij, C. P. Penatti, H. Cantarella, J. L. Morelli, F. J. Orlando, M. G. A. Landell, and R. Rossetto. 1996. Sugarcane. In: Fertilization and liming recommendations for the State of São Paulo, eds. B. V. Raij, H. Cantarella, J. A. Quaggio, and A. M. C. Furlani. Campinas: IAC.

Sumner, M. E., and A. D. Noble. 2003. Soil acidification: The world story. In: Handbook of soil acidity, ed. Z. Rengel. New York: Marcel Dekker.

Vitti, G. C. 1988. Evaluation and interpretation of sulfur in soils and plants. Jaboticabal: Funep. 